\title{
Alpha Cinnamomin Elicits a Defence Response against Phytophthora cinnamomi in Castanea sativa
}

\author{
C. Medeira, I. Maia, C. Ribeiro, \\ I. Candeias and E. Melo \\ INRB/INIA \\ Oeiras \\ Portugal
}

\author{
N. Sousa and A. Cravador \\ Universidade do Algarve \\ Campus de Gambelas \\ Faro \\ Portugal
}

Keywords: elicitin, resistance, ink disease, chestnut, pathogen defence, oomycete, biocontrol

\begin{abstract}
Phytophthora cinnamomi and $P$. cambivora are considered as the causal agents of Castanea sativa ink disease. These soil-borne plant pathogens invade and destroy the root system leading to the death of the trees.

Most Phytophthora species secrete elicitins, a group of unique highly conserved proteins that are able to enhance plant defence responses in a systemic acquired resistance manner against infection by several pathogens. A cluster of four elicitin genes was identified in $P$. cinnamomi. In previous works one of these elicitins, $\alpha$ cinnamomin was shown to restrict the invasion of root cortical tissues by $P$. cinnamomi preventing vascular colonization in cork and holm oak. In the present work, roots of chestnut plantlets grown in vitro were allowed to absorb $\alpha$-cinnamomin at $100 \mu \mathrm{g} / \mathrm{ml}$ for two days before being inoculated with $P$. cinnamomi. The effects of this elicitin on host-pathogen interaction were studied at histological and ultrastructural levels.

$P$. cinnamomi was restricted to the outer cortex of $65 \%$ of the roots pre-treated with $\alpha$-cinnamomin. In these roots, the vascular cylinders were free of pathogen. On the contrary, the pathogen reached the vascular cylinder, penetrating the phloem and xylem vessels in all non-treated assayed roots. The signs of pathogen degradation in the cortical parenchyma, mainly in the intercellular spaces, and the increase of a physical barrier in epidermal and sub-epidermal cell wall-media lamella and intercellular spaces by impregnation with phenol-like compounds strongly suggest that $\alpha$-cinnamomin induced in chestnut defence reactions against $P$. cinnamomi.
\end{abstract}

\section{INTRODUCTION}

A resurgence of ink disease in chestnuts in Europe has been noted since the end of the last century. This lethal disease is currently limiting the establishment of new groves and is threatening the survival of old ones.

Within the genus Phytophthora, several species are known to be responsible for heavy losses in crop production. Phytophthora cinnamomi and Phytophthora cambivora are considered as the ink disease of Castanea sativa causal agents. In the infected root system, there is extensive necrosis of the tap root that extends to the lateral roots and up the stem. Climatic changes, the global warming, enhance the impact on the decline and dieback of several food crop hosts due to the expansion of $P$. cinnamomi (Brasier and Scott, 1994; Bergot et al., 2004). The emergence of large number of pesticide resistant strains of pathogens justifies the great urgency of the substitution of chemicals by new biocontrol strategies in plant disease protection.

Successful plant pathogens have developed strategies to interfere with the defense mechanisms of their host plants through evolution. Conversely, host plants have evolved systems to counteract pathogen attack.

Defense mechanisms include constitutive and induced inhibitory compounds, cell wall reinforcement by deposition and crosslinking of polysaccharides, proteins, glycoproteins and insoluble phenolics and occlusion of xylem elements. 
It has been assumed that certain peptides released upon the action of extracellular proteinases of phytopathogenic microorganisms can act as elicitors, activating plant protection reactions (Valueva and Mosolov, 2004).

Phytophthora cinnamomi secretes elicitins, a group of highly conserved proteins that work as effectors and play an important role on the host-pathogen interaction (Ponchet et al., 1999; Kamoun, 2007; Horta, 2010). These elicitins are able to enhance plant defense responses leading to systemic acquired resistance against infection by several pathogens (Ricci et al., 1989, 1997; Piccard et al., 2000).

In $P$. cinnamomi a gene cluster consisting of four elicitins genes was identified (Duclos et al., 1998) and the crystal structure of cinnamomin was determined (Rodrigues et al., 2006). The elicitin $\alpha$-cinnamomin was shown to restrict the invasion of P. cinnamomi in root cortical tissues, preventing vascular colonization of cork and holm oak (Medeira et al., 2007). Horta et al. (2010) described and discussed the involvement of the $\beta$-cinnamomin elicitin in the infection and the colonization of cork oak roots.

This paper discusses and evaluates the defence reactions of chestnut plantlets grown in vitro against $P$. cinnamomi, pre-treated with $\alpha$-cinnamomin, searching for host defense reactions whose stimulation will be important in the context of a sustainable agriculture.

\section{MATERIALS AND METHODS}

\section{Plant Material}

In vitro chestnut plantlets were obtained from shoots raised on a modified MS medium, with half-strength $\mathrm{N}$ salts, containing $30 \mathrm{~g} / \mathrm{L}$ sucrose plus $0.5 \mathrm{mg} / \mathrm{L} \mathrm{BA}+$ $0.1 \mathrm{mg} / \mathrm{L}$ IAA. They were rooted on the same basal medium, without plant growth regulators and $3 \mathrm{~g} / \mathrm{L}$ charcoal, after a $2 \mathrm{~min}$ dip in a $2 \mathrm{~g} / \mathrm{L}$ IBA solution. When the roots had $1-2 \mathrm{~cm}$ the plantlets were transferred to new containers, placed over medium with the same composition but without charcoal and treated with $\alpha$-cinnamomin.

Ten $\mu \mathrm{l}$ of $\alpha$-cinnamomin water solution $(100 \mu \mathrm{g} / \mathrm{ml})$ were placed on each of the roots at about $5 \mathrm{~mm}$ from the cap during $48 \mathrm{~h}$, and after the roots were inoculated by introducing a plug of actively growing mycelium of $P$. cinnamomi, isolate $\mathrm{XX}-1 \mathrm{~B}$, lasting for 2 days.

\section{P. cinnamomi Culture and Growth Conditions}

The root pathogen $P$. cinnamomi isolate $\mathrm{XX}-1 \mathrm{~B}$ was grown on Difco potatodextrose agar (PDA, Difco Laboratories, Detroit, MI, USA) in $9 \mathrm{~cm}$ petri dishes for one week in dark conditions at $25^{\circ} \mathrm{C}$.

\section{Tissue Processing for Microscopic Studies}

From four plantlets per sample, 2 fine roots per plantlet were selected and 20 fragments of roots per sample about $1 \mathrm{~mm}^{3}$ were cut in the inoculated zone. The root fragments were fixed in $3 \%$ glutaraldehyde in $0.1 \mathrm{M}$ sodium cacodylate buffer, $\mathrm{pH} 7.2$ overnight at $4^{\circ} \mathrm{C}$. The fragments were washed three times for $30 \mathrm{~min}$ in the same buffer, post-fixed with $1 \%$ osmium tetroxide in $0.1 \mathrm{M}$ sodium cacodylate buffer, for $2 \mathrm{~h}$, dehydrated in an ethanol gradient to absolute ethanol and embedded in Spurr resin (Spurr, 1969).

Alternatively the root fragments were fixed in $0.1 \mathrm{M}$ cacodylate buffer ( $\mathrm{pH} 7.2$ ) containing 3\% (vol/vol), glutaraldehyde and 4\% (wt/vol) paraformaldehyde, for $4 \mathrm{~h}$ at $4^{\circ} \mathrm{C}$. Tissues fixed were washed in the same buffer, dehydrated in an ethanol gradient to absolute ethanol and embedded in LR White resin (London Resin Company).

Thick sections $(1-2 \mu \mathrm{m})$ and thin sections $(60-80 \mathrm{~nm})$ were obtained from a Leica Ultracut microtome, using diamond knives. The sections observed by light microscopy (LM) were stained with $0.05 \%$ toluidine blue in $1 \%$ sodium carbonate, or unstained and non-post-fixed in osmium tetroxide, observed under UV illumination with a Leica A filter set (excitation 340 to $380 \mathrm{~nm}$, barrier filter $425 \mathrm{~nm}$ ). Thin sections were stained with an 
aqueous saturated solution of uranyl acetate for $45 \mathrm{~min}$ and post-stained in a $3 \%$ aqueous solution of lead citrate at room temperature for $30 \mathrm{~min}$. The observations were made with a FEI Morgagni Transmission Electron Microscope (TEM) at $80 \mathrm{Kv}$.

\section{RESULTS}

\section{$\alpha$-Cinnamomin Treated Roots}

Forty eight hours after $\alpha$-cinnamomin absorption it was verified in the root cortex the accumulation of vacuolar precipitates stained brilliant green (Fig. 1) by the toluidine blue and autofluorescing blue green under UV (Fig. 2). These observations suggest a strong increase of phenol-like compounds in the vacuoles, cell walls and intercellular spaces of the cortical parenchyma, compared with the control (Fig. 3).

\section{$\alpha$-Cinnamomin Non-Treated and Infected Roots}

$P$. cinnamomi actively grew through the cortex invading extensive areas. Large intracellular hyphae (Fig. 4) as well as intercellular hyphae were observed (Fig. 5). The pathogen invaded the vascular cylinder, colonizing the phloem and xylem vessels (Fig. 6) in all the observed roots.

At the ultrastructural level the pathogen showed high metabolic activity in all the invaded root tissues. Large number of mitochondria and lipid bodies, well preserved membranes of the organelles indicate its healthy aspect.

\section{a-Cinnamomin-Treated and Infected Roots}

P. cinnamomi penetrated the outer cortical cell layers but its growth was restricted by the presence of a physical barrier due to an increase of thickness of cell wall-media lamella due to the deposition of osmiophilic materials which were also deposited in the intercellular spaces, intensely stained (Fig. 9) and autofluorescing under UV (Fig. 10). These materials impregnating the cell walls and intercellular spaces suggest the presence of phenol-like compounds.

The pathogen was restricted to the cortex not reaching the vascular cylinder in $65 \%$ of the $\alpha$-cinnamomin-treated root fragments, remaining the vascular cylinder free of P. cinnamomi (Fig. 11). The disorganization of the pathogen in the epidermal and subepidermal cells was associated with brilliant green materials stained by the toluidine blue (Fig. 12) in the host cell walls. Osmiophilic granular and fibrillar deposits around the damaged hyphae (Fig. 13) in the cortex were also associated with the disorganization of the pathogen. At the ultrastructural level the disorganization of the hyphae in the intercellular spaces was evident. The degradation of cell membranes led to the collapse of the organelles and loss of cytoplasmic contents of the hyphae (Figs. 14 and 15).

\section{DISCUSSION AND CONCLUSIONS}

The confinement of the pathogen in the outer cell layers of the cortex, preventing the colonization of the vascular cylinder in $65 \%$ of the root fragments pre-treated with $\alpha$-cinnamomin was an important knowledge in the attempt to search for new biocontrol strategies. In fact, all the infected and $\alpha$-cinnamomin non-treated roots had their vascular cylinders colonized in two days. These results are in accordance with our previous essays on other Fagaceae such as cork oak and holm oak (Medeira et al., 2007). The evidence of the pathogen degradation in the cortical parenchyma, mainly in the intercellular spaces was further confirmed at the ultrastructural level. The restriction of pathogen to the outermost root tissues of elicitin-treated plants was associated with the deposition of new materials in the colonized areas. Hyphae of the pathogen, surrounded by osmiophilic materials exhibited considerable changes including membrane disruption and cytoplasm rarefaction.

Elicitins have been successfully applied in several species to induce defense reactions against some pathogens due to newly-formed cell products. The elicitin-like cryptogein applied on tomato and on tobacco plants against $P$. parasitica induced the 
formation of phenolic compounds impregnating the cell walls and the pectins of the intercellular spaces (Picard et al., 2000; Lherminier et al., 2003). The formation of a calcium pectate gel in the colonized intercellular spaces of the cortical parenchyma was also detected (Lherminier et al., 2003). These cell alterations were considered as an increase of the physical barriers leading to the restriction of the pathogen invasion.

The degradation of the pathogen in the cortical tissues observed in chestnut roots may be due to the phenolic-like compounds with toxic properties. Although phenolic compounds impregnating cell walls, evidenced by their autofluorescence under UV may indirectly reinforce the strength of these barriers, the main contribution of these materials may be a direct toxicity, evidenced by the degradation of $P$. cinnamomi. Benhamou et al. (2001) proposed this effect of toxicity on root rot of tomato plants pre-treated with oligandrin against Fusarium oxysporum. The massive accumulation of toxic compounds at sites of attempted pathogen penetration was considered as a rapid and efficient response of oligandrin-treated tomato against $F$. oxysporum.

The signs of pathogen degradation in the cortical parenchyma, mainly in the intercellular spaces associated with phenol-like compounds strongly suggest that $\alpha$-cinnamomin induced in chestnut defense reactions against $P$. cinnamomi .

\section{ACKNOWLEDGEMENTS}

This work was supported by PTDC/AGR-AAM 67628 Project.

\section{Literature Cited}

Benhamou, N., Bélanger, R.R., Rey, P. and Tirilly, Y. 2001. Oligandrin, the elicitin-like protein produced by the mycoparasite Pythium oligandrum, induces systemic resistance to Fusarium crown and root rot in tomato plants. Plant Physiol Biochem. 39:681-698.

Bergot, M., Cloppet, E., Pérarnaud, V., Déqué, M., Marçais, B. and Desprez-Loustau, M.L. 2004. Simulation of potential range expansion of expansion of oak disease caused by Phytophthora cinnamomi under climate change. Global Change Biology 10:1429-1626.

Brasier, C. and Scott, J.K. 1994. European oak declines and global warming: a theoretical assessment with special reference to the activity of Phytophthora cinnamomi. Bulletin OEPP/ EPPO Bulletin 24:221-232.

Duclos, J., Fauconnier, A., Coelho, A.C., Bollen, A., Cravador, A. and Godfroid, E. 1998. Identification of an elicitin gene cluster in Phytophthora cinnamomi. DNA Sequence Journal of Sequencing and Mapping 9:231-237.

Horta, M., Caetano, P., Coelho, A.C., Medeira, C., Maia, I., Neves, D. and Cravador, A. 2010. Involvement of the $\beta$-cinnamomin elicitin in infection and colonisation of cork oak roots by Phytophthora cinnamomi. European Journal of Plant Pathology 127(3):427-436.

Kamoun, S. 2007. Groovy times: filamentous pathogen effectors revealed. Current Opinion in Plant Biology 10:358-365.

Lheirminier, J., Benhamou, N., Larrue, J., Milat, M.L., Boudon-Padieu, E., Nicole, M. and Blein, J.P. 2003. Cytological characterization of elicitin-induced protection in tobacco plants infected by Phytophthora parasitica or phytoplasma. Phytopathology 93(10):1308-1319.

Medeira, C., Maia, I., Sousa, N. and Cravador, A. 2007. Cinnamomin reduces the capacity of infection of cork oak and holm oak roots by $P$. cinnamomi. IUFRO Tree Biotechnology Congress, 3-8 June, Ponta Delgada, Azores (Abstracts): SII.9.

Rodrigues, M.L, Archer, M., Martel, P., Jacquet, A., Cravador, A. and Carrondo, M.A. 2006. Structure of $\beta$-cinnamomin, a protein toxic to some plant species. Biological Crystallography. Acta Crystallographica Section D 58:1314-1321.

Picard, K., Ponchet, M., Blein, J.P., Rey, P., Tirilly, Y. and Benhamou, N. 2000. Oligandrin, a proteinaceous molecule produced by the mycoparasite Pythium oligandrum induces resistance to Phytophthora parasitica infection in tomato plants. 
Plant Physiology 124:379-395.

Ponchet, M., Panabières, F., Milat, M.L., Mikes, V., Montillet, J.L. and Suty, L. 1999. Are elicitins cryptogams in the plant-oomycete communications? Cellular and Molecular Life Sciences 56:1020-1047.

Ricci, P. 1997. Induction of the hypersensitive response and systemic acquired resistance by fungal proteins: the case of elicitins. p.53-75. In: G. Stacey and T. Keen (eds.), Plant-Microbe Interactions. New York, USA, Chapman \& Hall.

Ricci, P., Bonnet, P., Huet, J.C., Sallatin, M., Beauvais-Caute, F., Bruneteau, M., Billard, V., Michel, G. and Pernollet, J.C. 1989. Structure and activity of proteins from pathogenic fungi Phytophthora eliciting necrosis and acquired resistance in tobacco. European Journal of Biochemistry 183:555-563.

Spurr, A.R. 1969. A low viscosity epoxy resin embedding medium for electron microscopy. Journal of Ultrastructure Research 26:31-43.

Valueva, T.A. and Mosolov, V.V. 2004. Role of inhibitors of proteolytic enzymes in plant defense against phytopathogenic microorganisms. Biochemistry (Moscow) 69(11): 1305-1309. Translated from Biokhimiya 69(11):1600-1606.

\section{Figures}

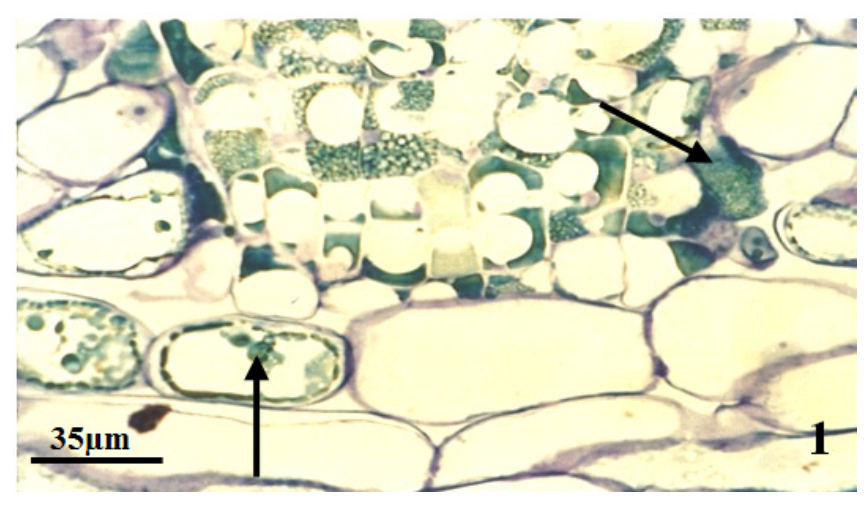

Fig. 1. $\alpha$-cinnamomin treated roots. (LM) - Toluidine blue staining. Accumulation of materials (arrows) stained brilliant green in the vacuoles and in the intercellular spaces of the inner layers of the cortical parenchyma.

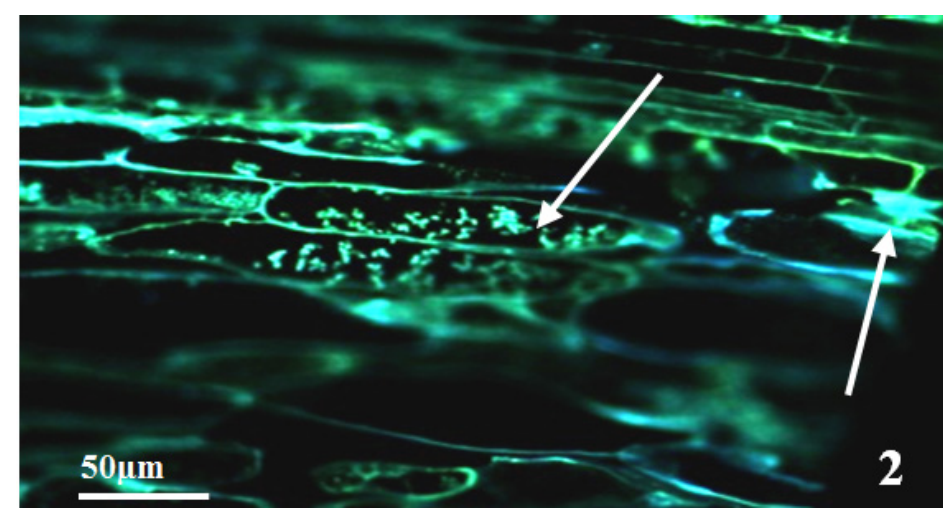

Fig. 2. $\alpha$-cinnamomin treated roots. (FM) - Autofluorescence of phenol-like deposits (arrows) in the vacuoles and along cell walls of the cortical parenchyma. 


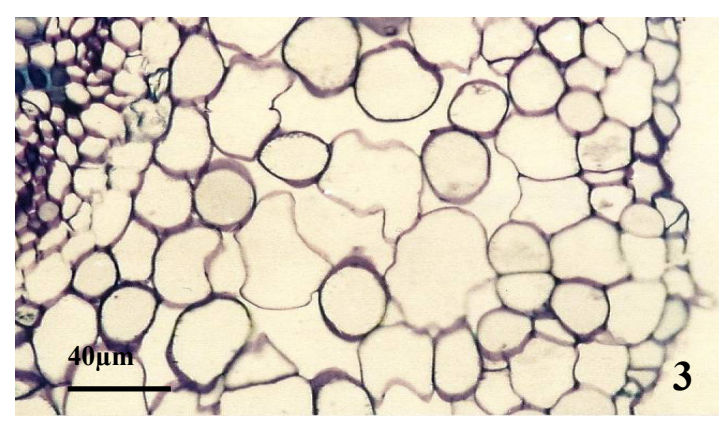

Fig. 3. (LM) - $\alpha$-cinnamomin non-treated root (control). Toluidine blue staining. The deposition of green stained phenol-like materials was not observed.

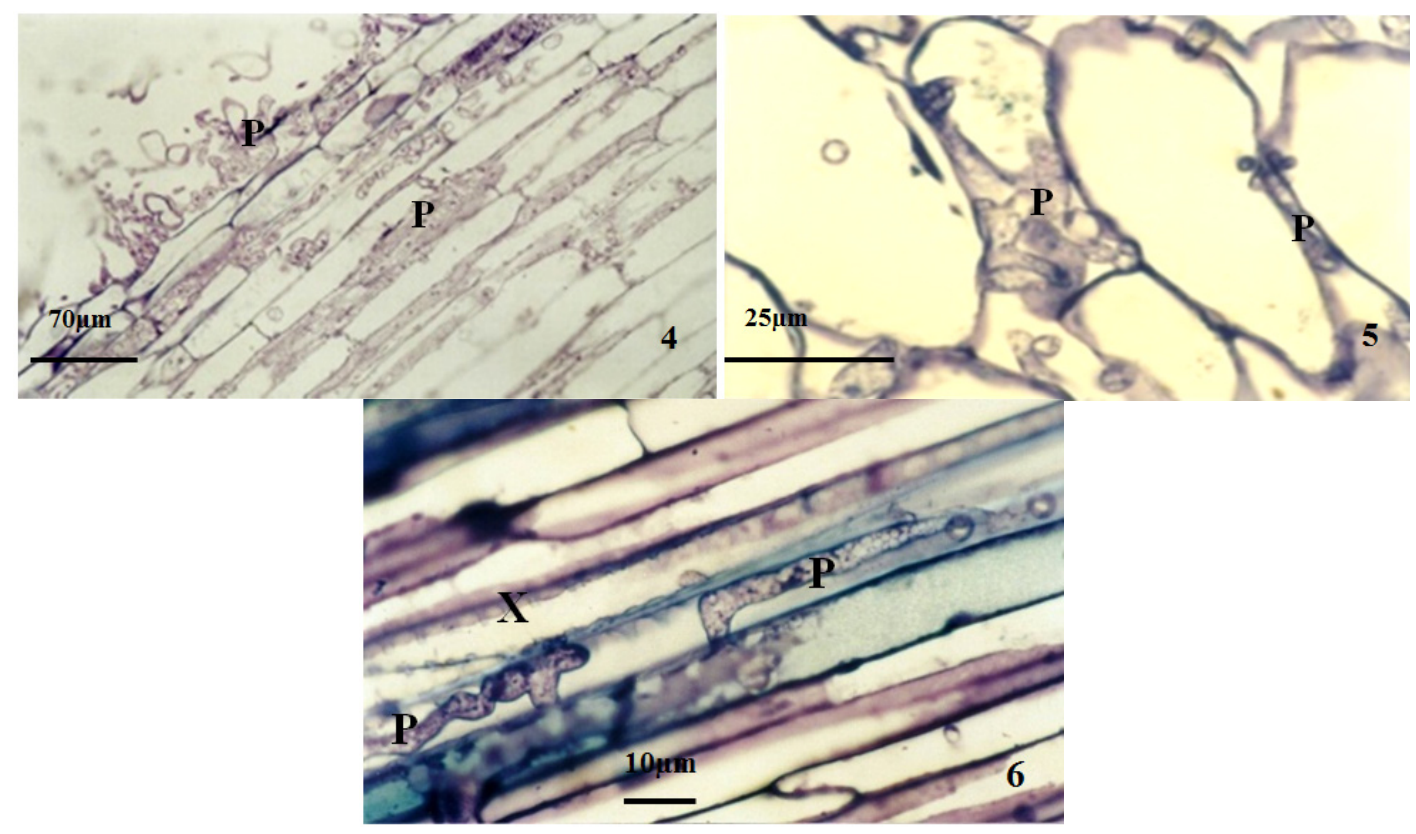

Figs. 4 to 6. (LM) - $\alpha$-cinnamomin non-treated and infected roots. Toluidine blue staining. P. cinnamomi $(\mathrm{P})$ invasion through extensive areas of the cortex (Figs. 4 and 5) and vascular cylinder (Fig. 6). Xylem-X.

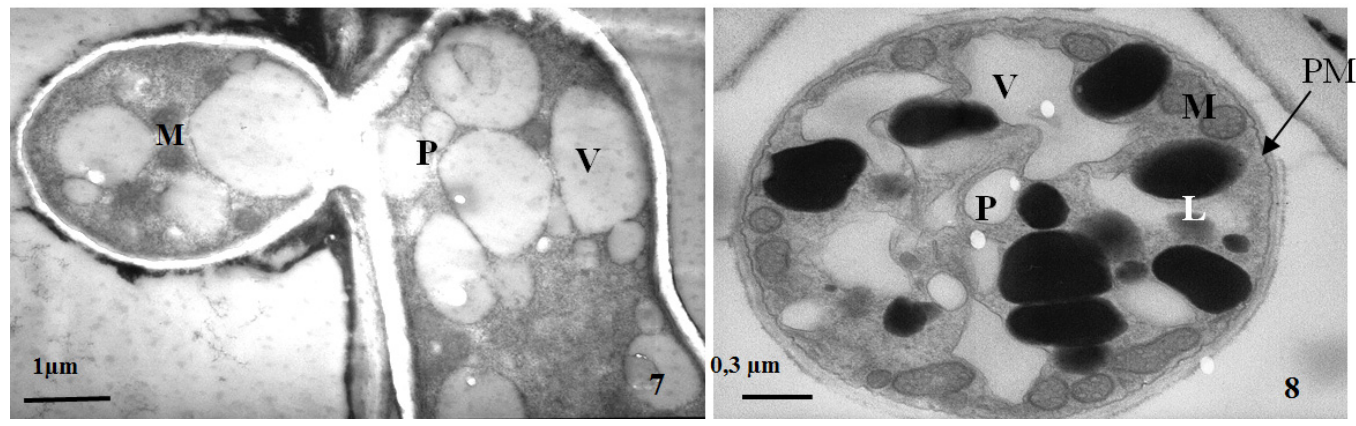

Figs. 7 and 8. $\alpha$-cinnamomin non-treated and infected roots. (TEM) - The pathogen presented a healthy appearance in the invaded root tissues with large number of mitochondria (M), small vacuoles (V) and lipid bodies (L), well preserved plasmalemma (PM) and organelle membranes. 

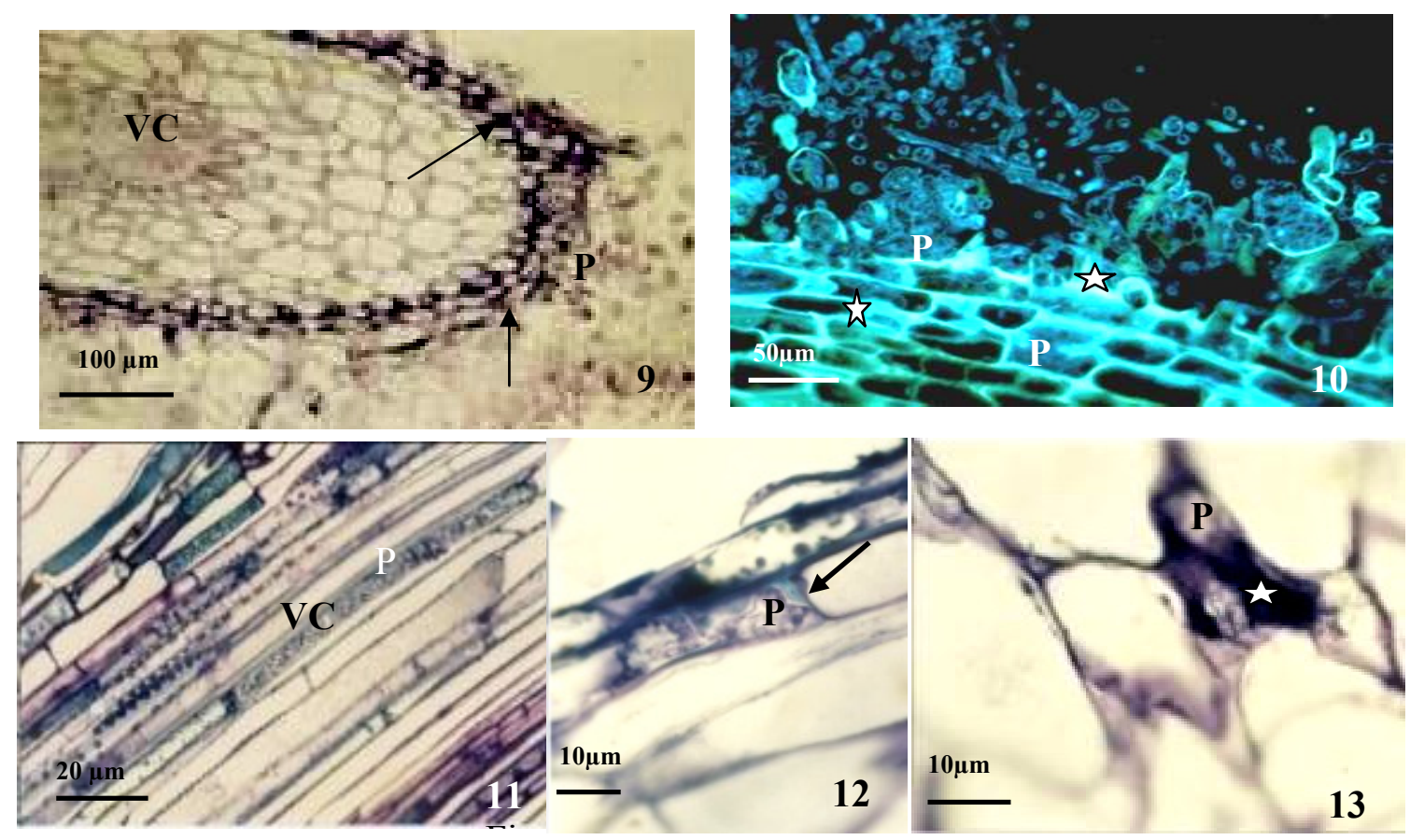

Figs. 9 to 13 . $\alpha$-cinnamomin-treated and infected roots. Figs. 9 and 11 to 13 (LM). Toluidine blue staining. Figs. 9 and 13 Post-fixation with osmium tetroxide. Fig. 10 (FM). Figs. 9 and 10 Restriction of pathogen invasion in the outer cortex. Cell wall, media lamella and intercellular spaces stained intensely (arrows) (Fig. 9) and autofluoresce under UV (Fig. 10) giving rise to a physical barrier (star) against pathogen (P) progression. The vascular cylinder (VC) was free of the pathogen. Fig. 12 Disorganization of $P$. cinnamomi (P) in epidermal and sub-epidermal cells associated with brilliant green phenol-like materials (arrow). Fig. 13 Osmiophilic granular and fibrillar deposits (star) around damaged hyphae (P) in the cortex.

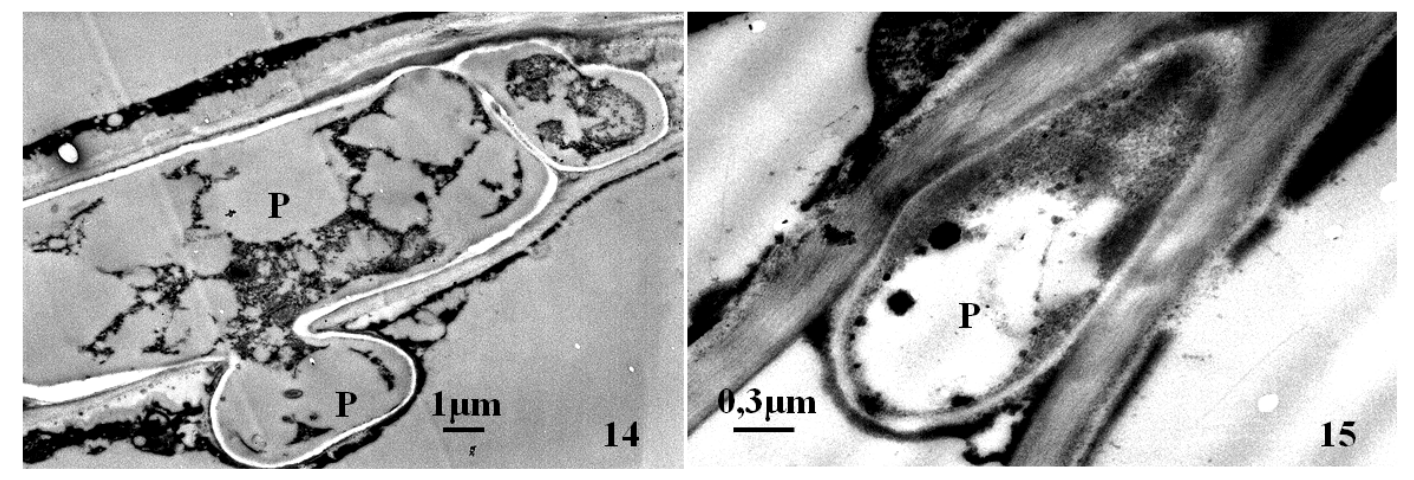

Figs. 14 and 15. $\alpha$-cinnamomin-treated and infected roots. (TEM) - Disorganization of the hyphae $(\mathrm{P})$ in the intercellular spaces of the cortex: degradation of cell membranes, collapse of organelles and loss of cytoplasm contents. 
